\title{
PENDEKATAN PSIKOLOGIS DALAM MENDAPATKAN KEPERCAYAAN KONSUMEN DARI KEGAGALAN PELAYANAN
}

\author{
WAODE MARATUN SHALEHA \\ AL ASY ARI ADNAN HAKIM \\ SELVI DILIYANTI RIZKI \\ Universitas Muhammadiyah Kendari, Jl. KH Ahmad Dahlan No. 10, Kendari Sulawesi Tenggara \\ wdmaratunshaleha@febi.umkendari.ac.id, alasyariadnanhakim@febi.umkendari.ac.id, \\ selvidr@febi.umkendari.ac.id
}

\begin{abstract}
The purpose of this study was to determine the effect of Value Co-cration on Perceived Justice, to determine the effect of Service Recovery on Perceived Justice, to determine the effect of Perceived Justice on Emotions and to determine the effect of Emotions on Repurchase Intentios. The sampling technique in this research is judgmental sample. This research was conducted for three months by distributing questionnaires via google form. The number of samples in this study were 300 respondents. The analytical tool used is SEM (Structural Equation Modeling). The results of this study are Utilitarian Value has a positive effect on Perceived Justice. Hedonic value has a negative effect on perceived justice, Making an Apology has a positive influence on perceived justice, Problem Solving has a positive influence on perceived justice, Being Courteous has a positive influence on perceived justice, Providing an explanation has a positive influence on perceived justice, Prompt Handling has Positive influence on the variable Perceived Justice, Perceived Justice has a negative effect on Negative Emotion, Perceived justice has a positive effect on positive emotions, Negative Emotion has a positive effect on Repurchase Intention and Positive Emotion has a positive effect on Repurchase Intention.
\end{abstract}

Keywords: Service failures, consumer confidence, consumer psychology, perceived justice

\begin{abstract}
Abstrak: Tujuan penelitian adalah untuk mengetahui pengaruh Value co-cration terhadap Perceived Justice, untuk mengetahui pengaruh Service recovery terhadap Perceived Justice, untuk mengetahui pengaruh Perceived Justice terhadap Emotions dan untuk mengetahui pengaruh Emotions terhadap Repurchase Intentios. Teknik pengambilan sampel dalam penelitian ini adalah judgemental sample. Penelitian ini dilakukan selama tiga bulan dengan cara menyebarkan kuesioner melalui google form. Jumlah sampel dalam penelitian ini adalah 300 responden. Alat analisis yang digunakan adalah SEM (Structural Equation Modeling). Hasil dari penelitian ini adalah Utilitarian Value berpengaruh positif terhadap Perceived Justice. Hedonic value memiliki pengaruh negative terhadap perceived justice, Making an Apology memiliki pengaruh positif terhadap Perceived Justice, Problem Solving memiliki pengaruh positif terhadap Perceived Justice, Being Courteous memiliki pengaruh positif terhadap Perceived Justice, Providing an Explanation memiliki pengaruh positif terhadap Perceived Justice, Prompt Handling memiliki pengaruh positif terhadap variabel Perceived Justice, Perceived Justice memiliki pengaruh negatif terhadap Negative Emotion, Perceived justice berpengaruh positif terhadap positive emotions, Negative Emotion memiliki pengaruh positif Repurchase Intention dan Positive Emotion berpengaruh positif terhadap Repurchase Intention
\end{abstract}

Kata kunci: Service failures, consumer confidence, consumer psychology, perceived justice 


\section{PENDAHULUAN}

Seiring dengan berkembangnya peningkatan taraf hidup seseorang, maka pemenuhan kebutuhan hidup tidak lagi terbatas pada kebutuhan fisiologi. Kebutuhan keselamatan akan rasa aman dan perlindungan kini juga semakin penting. Mengingat manusia tidak terlepas dari berbagai resiko yang menimbulkan kerugian.

Memiliki asuransi merupakan salah satu cara untuk pemenuhan kebutuhan akan rasa aman dan ketidakpastian yang terjadi pada hidup seseorang. Perusahaan asuransi merupakan lembaga keuangan nonbank yang mempunyai peranan yang tidak jauh berbeda dari bank, yaitu bergerak dalam bidang layanan jasa yang diberikan kepada masyarakat dalam mengatasi resiko yang terjadi di masa yang akan datang. Kinerja asuransi jiwa pada 2020 mengalami pertumbuhan sebesar 23,7 persen dibandingkan dengan pendapatan premi pada 2019 senilai Rp 12,46 triliun (Laporan lifepal, 2020). Perkembangan industry asuransi ditandai oleh banyaknya perusahaan yang menyediakan layanan jasa asuransi melalui berbagai produk dan promosi (Darwin, Sondang, and Et Al 2014).

Adanya peningkatan pertumbuhan permintaan asuransi dan tingginya tingkat persaingan usaha yang terjadi, maka dibutuhkan suatu upaya lebih dari setiap perusahaan asuransi dalam memberikan pelayanannya guna mempertahankan konsumen yang dimiliki. Salah satu upaya yang dilakukan adalah dengan menerapkan value co-creation. Value co-creation merupakan proses di mana pelanggan berperan aktif dalam menciptakan nilai bersama dengan perusahaan, aktivitas kepada pelanggan atau kostumisasi produk dan layanan. Ketika produk dan layanan diciptakan bersama, perusahaan harus memperlakukan pelanggan sebagai sumber kompetensi dan cara mencapai serta mempertahankan keunggulam kompetitif (Imperatori and Ruta 2014). Perusahaan yang sudah menjalankan proses co-creation dengan baik, maka value dari produk tersebut akan lebih baik dari produk yang dihasilkan (Kartajaya 2009).

Bagi sektor pelayanan jasa, kemungkinan kegagalan dalam pemberian layanan memiliki peluang yang lebih tinggi. Hal ini dikarenakan standar ekspektasi konsumen tidak sesuai dengan yang ditawarkan oleh perusahaan. Ketika kegagalan tidak dapat untuk dihindari, maka perusahaan harus berusaha untuk memperbaiki pelayanan yang diberikan. Bolton \& Mattila, (2015) pemulihan sangat penting dalam mempertahankan basis pelanggan yang stabil.

Park \& Ha (2016) mengemukakan bahwa umumnya penyebab kegagalan dalam pelayanan sangat ditentukan oleh value yang terdapat pada pelanggan itu sendiri seperti utilitarian value ataupun hedonic value. Utilitarian value adalah tindakan dari pembeli saat belanja dengan menentukan keputusan akan membeli barang tersebut ataupun tidak yang didasari oleh kebutuhan yang mereka inginkan atau yang mereka cari sedangkan hedonic value adalah sifat pada konsumen yang cenderung membeli tanpa mengutamakan prioritas berbelanja sesuai dengan kebutuhan (WM Shaleha, Al Asy Ari Adnan Hakim, and Nisrina Hamid 2020).

Kegagalan dalam pelayanan dapat dilakukan melaui tindakan, pemikiran, rencana dan proses untuk memperbaiki pelayanan bila terjadi kesalahan atau kekecawaan, sehingga pelanggan menjadi puas yang biasa disebut service recovery. Service recovery dapat dilakukan agar meningkatkan pembelian. Langkah-langkah tersebut terdiri dari making an apology, 
problem solving, being courteous, providing an explanation, prompt handling (Liao 2007). Making an apology adalah permintaan maaf secara umum mengacu pada pengakuan tanggung jawab atas peristiwa negatif yang meliputi beberapa ekspresi penyesalan. Problem solving adalah suatu upaya yang dilakukan dari salah satu pihak atas kesalahan yang telah dilakukan dengan cara menyelesaikan permasalahan dengan secara adil (MccollKennedy and Sparks 2003).

Sedangkan being courteous adalah perilaku pelayanan pelanggan karyawan yang menunjukkan kesopanan, menghormati, keramahan, dan kesabaran saat berinteraksi dengan pelanggan. Adapun yang dimaksud dengan providing an explonation adalah menjelaskan kepada pelanggan apa penyebab kegagalan dalam pelayanan. Prompt handling adalah penanganan yang cepat mengacu pada respon yang cepat dari pelayanan karyawan pada keluhan pelanggan.

Service recovery performance merupakan salah satu cara dalam menangani kegagalan dalam pelayanan dimana customer service secara langsung menangani keluhan pelanggan dan terlibat untuk memulihkan kepuasan dan loyalitas pelanggan setelah terjadi kegagalan dalam pelayanan (Liao 2007). Service recovery performance menyelesaikan kegagalan layanan untuk memenuhi harapan pelanggan (Luo et al. 2019). Service recovery performance adalah bagian penting dari suatu layanan dalam sebuah industry, sehingga karyawan harus menjaga kepuasan dan loyalitas pelanggan setelah terjadi kegagalan dalam layanan (Liao 2007). Tujuan dari setiap recovery response haruslah untuk memperbaiki masalah segera dan mengembalikan ekuitas ke potensi hubungan pelanggan-perusahaan yang rusak (Roggeveen, Tsiros, and Grewal 2012).
Ketika konsumen sudah menerima service recovery performance yang diberikan, hal yang perlu dirasakan konsumen dalah perceived justice, dimana dalam bidang ini perceived justice yang dirasakan semakin diidentifikasi sebagai pengaruh utama dalam pembentukan penilaian evaluative konsumen dari proses pemulihan (Schoefer and Ennew 2005). Dalam service recovery performance, perceived justice yang dirasakan semakin diidentifikasi sebagai pengaruh utama dalam pembentukan penilaian evaluatif konsumen dari proses pemulihan (La and Choi 2019).

Setelah pelanggan mendapatkan kepuasan dalam hak keadilan atau biasa disebut perceived justice maka hal tersebut akan mempengaruhi emosi dari pelanggan. Seperti negative emotions dimana hal ini diwakili oleh dua distrik kecemasan dan kebencian. Positive emotions yang dikonseptualisasikan sebagai kegembiraan dan harapan (Chebat and Slusarczyk 2005). Selain itu emosi juga dianggap memiliki peran penting dalam evaluasi konsumen. Dalam kategori umum proses afektif emotion diakui sebagai item penting dalam memahami konsumen dari berbagai perspektif berbeda (Schoefer and Ennew 2005). Dari aspek emotion akan mempengaruhi repurchase intention sebagai perilaku yang konsumen cari, menggunakan, membeli, mengevaluasi, dan membuang produk dan jasa yang diasumsikan untuk memenuhi kebutuhan konsumen.

Dari proses penciptaan nilai dan kegagalan dalam melayani konsumen serta upaya yang dilakukan pihak asuransi merupakan suatu cara untuk membangun loyalitas pelanggannya kembali, sehingga pelanggannya tersebut masih ingin menggunakan produk asuransi yang mereka tawarkan. Dalam hal ini merupakan repurchase intention dimana terdapat niat membeli kembali mengacu pada keputusan 
konsumen tentang mengulangi tindakan pembelian merek (Ebrahim et al. 2016).

Penelitian ini bertujuan untuk (1) membuktikan pengaruh value co-cration terhadap perceived justrice, (2) untuk mengetahui pengaruh service recovery terhadap perceived justice, (3) untuk mengetahui pengaruh perceived justice terhadap emotions dan (4) untuk mengetahui pengaruh emotions terhadap purchase intentions.

Originalitas artikel ini adalah terfokus pada menciptakan suatu model dari aspek psikologis, guna mengatasi permasalahan kekecewaan konsumen atas kegagalan pelayanan.

\section{Value Co-Creation}

Co-creation adalah proses di mana pelanggan berperan aktif dalam menciptakan nilai bersama dengan perusahaan (Ramaswamy 2008). Value cocreation merupakan pendekatan yang menarik bagi perusahaan karena berbagai alasan. Misalnya, ide yang dihasilkan melalui penciptaan nilai bersama akan lebih mencerminkan kebutuhan konsumen, dan partisipasi konsumen dalam konsumsi layanan dapat meningkatkan persepsi kualitas dan mengurangi ketidakpastian dan risiko (Imperatori and Ruta 2014).

Value co-creation adalah ketika pelanggan menggunakan produk atau jasa untuk memenuhi kebutuhan atau keinginan mereka yang disebut sebagai nilai pakai (Park and $\mathrm{Ha}$ 2016). Value co-creation didefinisikan sebagai kreasi pelanggan dari nilai dalam penggunaan suatu barang atau jasa (Grönroos 2011).

Holbrook, (2006), pendekatan yang melibatkan konstruksi skala atau indeks untuk mengukur berbagai jenis nilai pelanggan yaitu utilitarian value dan hedonic value. Nilai utilitarian menunjukkan sebuah evaluasi pelanggan tentang seberapa efisien dan bermanfaat sebuah penciptaan dalam pemulihan layanan setelah memenuhi tujuan pelanggan. Perceived justice juga memainkan peran penting dalam pemulihan pelayanan. Pelanggan juga peduli tentang keadilan dan mengharapkan untuk diperlakukan secara adil dalam mengalami pelayanan. Sehingga ketika pelanggan mendapatkan kepuasan dari pemulihan pelayanan maka pelanggan akan melakukan niat pembelian kembali.

Nilai hedonic muncul sebagai dua wujud yang bekerjasama dalam cara yang menyenangkan dan sangat menghargai ketika memiliki fleksibilitas yang besar untuk beradaptasi dengan berbagai layanan. Keadilan disebabkan karena melayani beberapa hal penting, kebutuhan psikologis mendasar yang penting untuk manusia untuk mengontrol lingkungan, untuk mendapatkan jangka panjang dari manfaat ekonomi, untuk mempertahankan diri dari hal positif dan mencapai status dan harga diri dari orang lain, dan untuk menghormati martabat manusia dan kelayakan hidup yang baik. Sehingga ketika pelanggan merasa dihargai dan dihormati makan pelanggan akan melakukan niat pembelian kembali.

\section{Service Recovery}

Service recovery adalah tindakan penyedia layanan untuk mengurangi dan memperbaiki kerusakan pada pelanggan yang diakibatkan oleh kegagalan penyedia untuk memberikan layanan sebagaimana yang dirancang (Hoffman and Kelley 2000). Service recovery sebagai tindakan, pemikiran, rencana, dan proses untuk memperbaiki pelayanan bila terjadi kesalahan atau kekecewaan sehingga pelanggan menjadi puas (Wardhana 2015). Service recovery bukan hanya tentang menangani konsumen yang tidak puas tetapi juga untuk mendapatkan Kembali keuasan 
dan loyalitas konsumen (Maneesh Kumar Niraj Kumar 2016).

Kinerja pemulihan layanan mengatasi kegagalan layanan untuk memuaskan dan memenuhi harapan pelanggan. Literatur kinerja pemulihan layanan berfokus pada mengeksplorasi peran kinerja pemulihan layanan karyawan dalam menerjemahkan fungsi internal organisasi layanan menjadi hasil pelanggan eksternal yang diinginkan (Luo et al. 2019). Liao (2007) ada beberapa langkah-langkah yang dapat dilakukan dalam service recovery yaitu; Making an Apology, Dalam menangani keluhan pelanggan, perusahaan menerima tanggung jawab atas kegagalan layanan dan menyesal atas apa yang telah terjadi dengan membuat permintaan maaf kepada pelanggan. Penelitian keadilan menyoroti mengapa membuat permintaan maaf adalah penting dalam pemulihan layanan. Permintaan maaf dipandang sebagai hadiah berharga yang mendistribusikan kembali hubungan yang melekat dan kepedulian kepada pelanggan yang telah mengalami ketidaknyamanan. Permintaan maaf telah terbukti meningkatkan keadilan yang dirasakan oleh pelanggan. Setelah pelanggan merasa adil maka pelanggan mempunyai kemungkinan untuk membeli kembali.

Problem Solving kemampuan kerja karyawan untuk memecahkan masalah layanan telah terbukti mempengaruhi kepuasan pelanggan dan evaluasi layanan kualitas. Jika pelayanan karyawan gagal untuk memecahkan masalah, pelanggan akan merasa bahwa mereka belum menerima hasil yang mereka harapkan dan pantas, kebijakan dan prosedur pemulihan layanan organisasi tidak memadai dalam menghasilkan solusi yang tepat. Akibatnya, pemecahan masalah yang tidak memadai akan menghasilkan ketidakadilan yang dirasakan. Sehingga ketika pelanggan tidak mendapatkan keadilan dalam pelayanan niat untuk pembelian kembali mungkin tidak akan terjadi.

Being Courteous, kesopanan karyawan dalam menangani keluhan pelanggan membantu meredakan masalah dalam pikiran pelanggan, jika karyawan bertindak kasar saat menangani keluhan pelanggan, hasilnya bisa menjadi bencana. Keadilan pelanggan dianggap dapat bertindak sebagai mekanisme mediasi di mana perilaku sopan mempengaruhi kepuasan pelanggan. Keadilan dipupuk ketika individu merasa mereka diperlakukan dengan hormat, martabat, dan sensitivitas. Providing an Explanation, dalam konteks pemulihan layanan, komunikasi terbuka dapat mengurangi perasaan buruk pelanggan tentang kegagalan pelayanan. Penjelasan itu sendiri dapat dilihat oleh pelanggan sebagai bagian penting dari informasi, hasil yang berharga, dan sarana untuk memahami dan mengendalikan lingkungan pelayanan mereka sehingga meningkatkan keadilan yang dapat dirasakan oleh pelanggan. Prompt Handling, penanganan yang cepat mengacu pada respon yang cepat dari pelayanan karyawan pada keluhan pelanggan. Kecepatan respon telah dikaitkan dengan kepuasaan pelanggan dalam literatur pemulihan pelayanan. Penelitian keadilan juga menunjukkan ketepatan waktu pengambilan keputusan pengaruh tentang keputusan keadilan yang akan dicapai.

\section{Perceived Justice}

Perceived justice adalah suatu evaluative penilaian tentang kebenaran nasib atau perlakuan seseorang kepada orang lain (Barakat et al. 2015). Perceived justice merupakan proses pemulihan tersendiri, hasil yang terkait dengan strategi pemulihan dan perilaku interpersonal yang dilakukan selama proses recovery (Hoffman and Kelley 2000). Perceived justice di anggap sebagai evaluasi yang berfokus 
pada diri sendiri berdasarkan pertukaran antara kerugian yang disebabkan oleh kegagalan layanan dan keuntungan dari pemulihan layanan.(La and Choi 2019). Perceived justice merupakan pengaruh utama dalam pembentukan penilaian evaluative konsumen tentang pemulihan proses (Schoefer and Ennew 2005).

Ketidakadilan dapat mengancam setiap dan semua kebutuhan, sehingga dapat memicu kognisi defensive individu, pengaruh negatif, dan pembatasan perilaku. Pelanggan juga peduli tentang keadilan dan mengharapkan untuk diperlakukan secara adil dalam mengalami pelayanan. Ketika pelayanan gagal, keluhan pelanggan mengaktifkan urutan interaksi antara pelanggan dan penyedia layanan, dimana keputusan penyelesaian keluhan dibuat dan ditentukan oleh hasil ekonomi dan sosial yang dialokasikan kepada pelanggan.. Didalam Perceived Justice terdapat beberapa jenis keadilan. Apakah pelanggan menerima hasil ekonomi atau sosial yang adil setelah mereka mengeluh tentang masalah layanan, apakah pelanggan mendapat keadilan tentang kebijakan dan prosedur yang digunakan untuk menyelesaikan keluhan, apakah pelanggan mendapatkan keadilan informasi, dan apakah pelanggan mendapatkan keadilan antar pribadi dengan baik. Jika semua keadilan tersebut dapat terpenuhi maka emosi dari pelanggan akan menjadi positif.

\section{Emotions}

Emotions dijelaskan dengan kompleksitas variabel "emosi", kekayaan, keragaman dan keunikan pengalaman emosional individu (Andries 2011). Diskrit dasar emosi disebabkan oleh warisan genetic yang bersifat universal menurut Charles Darwin (1967) dalam (Andries 2011) mengidentifikasi delapan emosi dasar, yaitu penderitaan, kesedihan atau depresi, kegembiraan, malaise, kebencian dan marah, penghinaan dan jijik, kejutan, ketakutan, dan malu. Emotions didefinisikan sebagai klasifikasi mental yang subjektif, dialami secara sadar, dan biasanya sejalan dengan emosi dan suasana hati (Simanjuntak et al. 2020).

Emosi negatif umumnya sulit untuk mengelola kehidupan orang yang merasa bahwa perilaku mereka tidak terkontrol (perasaan dipicu dan / atau dikelola oleh ketidakmampuan subjek yang dirasakan untuk mengontrol jalannya peristiwa). Apakah ancaman itu nyata atau tidak, emosi negatif dapat berhubungan dengan perasaan tidak berdaya dan mengaktifkan mekanisme pertahanan ego seperti menghindari, penarikan diri, penolakan, perpindahan, dan konfrontasi agresif.

Emosi positif berhubungan dengan peningkatan kreativitas, fleksibilitas kognitif, produktivitas tenaga kerja dan kepuasan profesional, ketersediaan komunikasi dan negosiasi keterampilan. Emosi positif, dengan menyelenggarakan dan efek konstruktif, mengoptimalkan kualitas pekerjaan. Emosi positif berhubungan dengan peningkatan kreativitas, spontanitas dan responsif terhadap rangsangan, pengaruh bagaimana keterlibatan mudah dalam pendekatan profesional dan konstruktif dan tugas kreatif dengan mengeksplorasi cara-cara baru untuk memenuhi persyaratan dari kegiatan profesional.

\section{Repurchase Intention}

Repurchase intention adalah niat membeli kembali adalah pertimbangan pengambilan keputusan untuk berulang kali membeli produk dari penjual sebelumnya atau yang sama oleh memperkirakan situasi dan keadaan saat ini (Simanjuntak et al. 2020). 
Repurchase intenton mencerminkan niat konsumen mengulangi tindakan perilaku membeli merek (Ebrahim et al. 2016). Repurchase intention didefinisikan sebagai penilaian individu tentang membeli layanan lagi, keputusan untuk terlibat dalam aktivitas masa depan dengan penyedia layanan dan apa bentuk aktivitas ini akan diambil (Chen and Chen 2017).

\section{METODE PENELITIAN}

Penelitian ini adalah penelitian kausal dengan subjek penelitian konsumen asuransi yang pernah kecewa atas pelayanan asuransi. Adapun Teknik pengambilan sampel dalam penelitian ini adalah judgemental sample. Penelitian ini dilakukan selama tiga bulan dengan cara menyebarkan kuesioner melalui google form. Jumah sampel dalam penelitian ini adalah 300 responden. Alat analisis yang digunakan adalah SEM (Structural Equation Modeling). Pengukuran variabel penelitian dapat dlihat dari table berikut:

Table 1 Variabel dan Indikator Variabel

\begin{tabular}{|c|c|c|c|}
\hline Konstruk & No & Item & Skala \\
\hline \multirow[t]{5}{*}{$\begin{array}{l}\text { Utilitarian } \\
\text { Value }\end{array}$} & 1 & $\begin{array}{l}\text { Saya sangat mengandalkan Asuransi "X" (Chaudhuri dan } \\
\text { Holbrook, 2001) }\end{array}$ & $1-5$ \\
\hline & 2 & $\begin{array}{l}\text { Asuransi "X" merupakan keharusan bagi saya } \\
\text { (Chaudhuri dan Holbrook, 2001) }\end{array}$ & $1-5$ \\
\hline & 3 & $\begin{array}{l}\text { Asuransi "X" termasuk yang paling murah (Ferrand, et } \\
\text { al., 2010) }\end{array}$ & $1-5$ \\
\hline & 4 & $\begin{array}{l}\text { Asuransi "X" mempunyai kualitas yang bagus (Ferrand, } \\
\text { et al., 2010) }\end{array}$ & $1-5$ \\
\hline & 5 & $\begin{array}{l}\text { Pelayanan dari Asuransi "X" memuaskan (Ferrand, et al., } \\
\text { 2010) }\end{array}$ & $1-5$ \\
\hline \multirow[t]{5}{*}{$\begin{array}{l}\text { Hedonic } \\
\text { Value }\end{array}$} & 6 & $\begin{array}{l}\text { Saya membeli Asuransi "X" hanya untuk kesenangan ( } \\
\text { Holbrook, 1982) }\end{array}$ & $1-5$ \\
\hline & 7 & $\begin{array}{l}\text { Saya membeli Asuransi "X" hanya untuk pengalaman } \\
\text { sosial (Kang dan Poaps ,2010) }\end{array}$ & $1-5$ \\
\hline & 8 & $\begin{array}{l}\text { Saya membeli Asuransi "X" hanya untuk hiburan (Kang } \\
\text { dan Poaps ,2010) }\end{array}$ & $1-5$ \\
\hline & 9 & $\begin{array}{l}\text { Saya membeli Asuransi "X" untuk menghindari perkataan } \\
\text { orang (Bobbles,1975) }\end{array}$ & $1-5$ \\
\hline & 10 & $\begin{array}{l}\text { Saya membeli Asuransi "X" hanya untuk rasa ingin tahu } \\
\text { (Bobbles,1975) }\end{array}$ & $1-5$ \\
\hline \multirow[t]{3}{*}{$\begin{array}{l}\text { Making an } \\
\text { Apology }\end{array}$} & 11 & $\begin{array}{l}\text { Perusahaan Asuransi "X" meminta maaf ketika bersalah } \\
(\text { Liao, 2007) }\end{array}$ & $1-5$ \\
\hline & 12 & $\begin{array}{l}\text { Perusahaan Asuransi "X" bertanggung jawab jika } \\
\text { bersalah (Liao, 2007) }\end{array}$ & $1-5$ \\
\hline & 13 & Perusahaan Asuransi "X" menyesal dengan kesalahan & $1-5$ \\
\hline
\end{tabular}




\begin{tabular}{|c|c|c|c|}
\hline & & yang telah diperbuat (Liao, 2007) & \\
\hline & 14 & $\begin{array}{l}\text { Perusahaan Asuransi "X" fokus terhadap pelayanan } \\
\text { pelanggan (Liao, 2007) }\end{array}$ & $1-5$ \\
\hline & 15 & $\begin{array}{l}\text { Perusahaan Asuransi "X" memberikan ekspresi merasa } \\
\text { bersalah (Liao, 2007) }\end{array}$ & $1-5$ \\
\hline \multirow[t]{5}{*}{$\begin{array}{l}\text { Problem } \\
\text { Solving }\end{array}$} & 16 & $\begin{array}{l}\text { Perusahaan Asuransi "X" mengkoreksi kesalahan } \\
\text { (McColl Kennedy \& Sparks, 2003) }\end{array}$ & $1-5$ \\
\hline & 17 & $\begin{array}{l}\text { Perusahaan Asuransi "X" cepat menyelesaikan } \\
\text { kesalahan yang terjadi (Barakat et al. , 2015) }\end{array}$ & $1-5$ \\
\hline & 18 & $\begin{array}{l}\text { Perusahaan Asuransi "X" menanyakan pendapat } \\
\text { nasabah tentang menyelesaikan masalah (Barakat et al. } \\
\text {, 2015) }\end{array}$ & $1-5$ \\
\hline & 19 & $\begin{array}{l}\text { Perusahaan Asuransi "X" memiliki sistem yang sangat } \\
\text { fleksibel (Barakat et al. , 2015) }\end{array}$ & $1-5$ \\
\hline & 20 & $\begin{array}{l}\text { Karyawan perusahaan Asuransi "X" terlihat benar-benar } \\
\text { tertarik dalam menyelesaikan masalah (Barakat et al. , } \\
\text { 2015) }\end{array}$ & $1-5$ \\
\hline \multirow[t]{5}{*}{$\begin{array}{l}\text { Being } \\
\text { Courteous }\end{array}$} & 21 & $\begin{array}{l}\text { Karyawan perusahaan Asuransi "X" mendengarkan } \\
\text { keluhan dengan sopan (Liao, 2007) }\end{array}$ & $1-5$ \\
\hline & 22 & $\begin{array}{l}\text { Karyawan perusahaan Asuransi "X" tidak membantu } \\
\text { meredakan masalah (Liao, 2007) }\end{array}$ & $1-5$ \\
\hline & 23 & $\begin{array}{l}\text { Karyawan perusahaan Asuransi "X" menghargai keluhan } \\
\text { pelanggan (Liao, 2007) }\end{array}$ & $1-5$ \\
\hline & 24 & $\begin{array}{l}\text { Karyawan perusahaan Asuransi "X" sabar ketika } \\
\text { berinteraksi dengan pelanggan (Liao,2007) }\end{array}$ & $1-5$ \\
\hline & 25 & $\begin{array}{l}\text { Perusahaan Asuransi "X" memberikan hasil yang layak } \\
\text { kepada pelangan (Liao,2007) }\end{array}$ & $1-5$ \\
\hline \multirow[t]{5}{*}{$\begin{array}{l}\text { Providing an } \\
\text { Explanation }\end{array}$} & 26 & $\begin{array}{l}\text { Karyawan perusahaan Asuransi "X" menjelaskan } \\
\text { penyebab kegagalan tersebut (Liao, 2007) }\end{array}$ & $1-5$ \\
\hline & 27 & $\begin{array}{l}\text { Perusahaan Asuransi "X" membuat komunikasi terbuka } \\
(\text { Liao, 2007) }\end{array}$ & $1-5$ \\
\hline & 28 & $\begin{array}{l}\text { Perusahaan Asuransi "X" meningkatkan pengertian } \\
\text { kepada pelanggan (Liao, 2007) }\end{array}$ & $1-5$ \\
\hline & 29 & $\begin{array}{l}\text { Perusahaan Asuransi "X" mengambil kesimpulan dari } \\
\text { kesalahan yang terjadi (Liao, 2007) }\end{array}$ & $1-5$ \\
\hline & 30 & $\begin{array}{l}\text { Perusahaan Asuransi "X" meringankan perasaan negatif } \\
\text { pelanggan terhadap produk (Liao, 2007) }\end{array}$ & $1-5$ \\
\hline $\begin{array}{l}\text { Prompt } \\
\text { Handling }\end{array}$ & 31 & $\begin{array}{l}\text { Perusahaan Asuransi "X" merespon dengan cepat (Liao, } \\
\text { 2007) }\end{array}$ & $1-5$ \\
\hline
\end{tabular}




\begin{tabular}{|c|c|c|c|}
\hline & 32 & $\begin{array}{l}\text { Perusahaan Asuransi "X" tidak menemukan jalan keluar } \\
\text { yang tepat (Liao, 2007) }\end{array}$ & $1-5$ \\
\hline & 33 & $\begin{array}{l}\text { Perusahaan Asuransi "X" membuat keputusan dengan } \\
\text { tepat (Liao, 2007) }\end{array}$ & $1-5$ \\
\hline & 34 & $\begin{array}{l}\text { Perusahaan Asuransi "X" memberikan hasil yang } \\
\text { berharga (Liao, 2007) }\end{array}$ & $1-5$ \\
\hline & 35 & $\begin{array}{l}\text { Perusahaan Asuransi "X" memberikan hasil yang layak } \\
\text { kepada pelangan (Liao, 2007) }\end{array}$ & $1-5$ \\
\hline \multirow{5}{*}{$\begin{array}{l}\text { Perceived } \\
\text { Justice }\end{array}$} & 36 & Hasil yang diterima saya adalah adil (Park \& Ha, 2015) & $1-5$ \\
\hline & 37 & $\begin{array}{l}\text { Saya mendapatkan apa yang seharusnya didapatkan } \\
\text { (Park \& Ha, 2015) }\end{array}$ & $1-5$ \\
\hline & 38 & $\begin{array}{l}\text { Saya mendapatkan informasi yang dibutuhkan (Liao, } \\
\text { 2007) }\end{array}$ & $1-5$ \\
\hline & 39 & Saya mendapatkan komunikasi yang baik (Liao, 2007) & $1-5$ \\
\hline & 40 & $\begin{array}{l}\text { Saya mendapatkan solusi dari masalah yang dihadapi } \\
\text { (Liao, 2007) }\end{array}$ & $1-5$ \\
\hline \multirow{5}{*}{$\begin{array}{l}\text { Negative } \\
\text { Emotions }\end{array}$} & 41 & Saya kecewa dengan produk ini (Bolton \& Mattila, 2015) & $1-5$ \\
\hline & 42 & $\begin{array}{l}\text { Saya tidak akan melanjutkan hubungan dengan } \\
\text { perusahaan ini (Casidy \& Shin, 2015) }\end{array}$ & $1-5$ \\
\hline & 43 & $\begin{array}{l}\text { Saya akan menyebarkan hal negatif dari perusahaan ini } \\
\text { (Casidy \& Shin, 2015) }\end{array}$ & $1-5$ \\
\hline & 44 & $\begin{array}{l}\text { Saya akan memperingatkan orang lain untuk tidak } \\
\text { menggunakan produk ini (Casidy \& Shin, 2015) }\end{array}$ & $1-5$ \\
\hline & 45 & $\begin{array}{l}\text { Saya tidak akan menggunakan produk ini meskipun } \\
\text { diberi manfaat yang lebih (Barakat et al. , 2015) }\end{array}$ & $1-5$ \\
\hline \multirow[t]{5}{*}{$\begin{array}{l}\text { Positive } \\
\text { Emotions }\end{array}$} & 46 & $\begin{array}{l}\text { Saya akan membayar dengan harga yang tinggi untuk } \\
\text { produk ini (Bolton \& Mattila, 2015) }\end{array}$ & $1-5$ \\
\hline & 47 & $\begin{array}{l}\text { Saya akan memberikan kesempatan kepada perusahaan } \\
\text { untuk memperbaiki kesalahan (Casidy \& Shin, 2015) }\end{array}$ & $1-5$ \\
\hline & 48 & $\begin{array}{l}\text { Keputusan saya menggunakan produk ini adalah } \\
\text { keputusan yang bijak (Barakat et al. , 2015) }\end{array}$ & $1-5$ \\
\hline & 49 & $\begin{array}{l}\text { Saya senang dengan keputusan yang sudah diambil } \\
\text { (Barakat et al. , 2015) }\end{array}$ & $1-5$ \\
\hline & 50 & $\begin{array}{l}\text { Perusahaan Asuransi "X" ini sangat terpercaya (Barakat } \\
\text { et al. , 2015) }\end{array}$ & $1-5$ \\
\hline $\begin{array}{l}\text { Repurchase } \\
\text { Intention }\end{array}$ & 51 & $\begin{array}{l}\text { Saya akan membeli produk ini lagi ketika income } \\
\text { bertambah (Park \& Ha, 2015) }\end{array}$ & $1-5$ \\
\hline
\end{tabular}




\begin{tabular}{clc}
\hline 52 & $\begin{array}{l}\text { Kabarkan saya jika ada manfaat baru dari produk ini } \\
\text { (Park \& Ha, 2015) }\end{array}$ & $1-5$ \\
53 & $\begin{array}{l}\text { Saya akan memperkenalkan produk ini kepada keluarga } \\
\text { lain (Park \& Ha, 2015) }\end{array}$ & $1-5$ \\
54 & $\begin{array}{l}\text { Saya akan mencegah orang lain untuk menjelekkan } \\
\text { perusahaan ini (Bolton \& Mattila, 2015) } \\
55\end{array}$ & $\begin{array}{l}\text { Saya menyukai produk ini lebih dari produk yang lain } \\
\text { (Schumann et al., 2014) }\end{array}$ \\
\hline
\end{tabular}

HASIL

\section{Utilitarian Value Terhadap Perceived Justice}

Utilitarian Value berpengaruh positif terhadap Perceived Justice. Aspek utilitarian dari pengalaman konsumsi telah lama dianggap sebagai dasar dari reaksi positif pelanggan. Mengingat bahwa nilai utilitarian sebagian besar mencerminkan persepsi dari pelanggan dari sejauh mana service recovery berguna dan efisien maka ada kemungkinan bahwa nilai utilitarian mengarah kepada keadilan yang dirasakan pelanggan. Hal ini sejalan dengan penelitian yang dilakukan oleh (Park and $\mathrm{Ha}$ 2016) bahwa nilai utilitarian meningkatkan ekuitas yang baik dan mempengaruhi arah pemulihan layanan. Ketika pelanggan percaya bahwa co-creation dapat memberikan pemulihan secara efisian maka keadilan dalam sebuah hubungan akan meningkat. Ada 2 indikator dalam utillitarian value yang mempengaruhi perceived justice seperti nasabah sangat mengandalkan asuransi yang mereka pilih dan asuransi tersebut merupakan keharusan bagi mereka.

\section{Hedonic Value Terhadap Perceived Justice}

Hedonic value memiliki pengaruh negative terhadap perceived justice. Hal ini tidak sejalan dengan penelitian yang dilakukan oleh (Park and Ha 2016) bahwa hedonic value memiliki pengaruh positif terhadap perceived justice. kegagalan dalam pelayanan dapat mengakibatkan hilangnya nilai ekonomi seperti uang, waktu, harga diri serta sumber daya sosial bagi pelanggan. Jadi menurut hasil penelitian sebelumnya ketika seorang pelanggan percaya bahwa mereka mendapat layanan emosional menyenangkan maka keadilan dapat semakin meningkat. Beberapa Indikator yang mempengaruhi adalah nasabah membeli asuransi tersebut hanya untuk hiburan, nasabah membeli asuransi tersebut untuk menghindari perkataan orang, nasabah membeli asuransi tersebut hanya untuk rasa ingin tahu sehingga nasabah tidak mendapat keadilan yang diinginkan. Selain itu nilai hedonik hanya menyumbang penambahan ekuitas. 


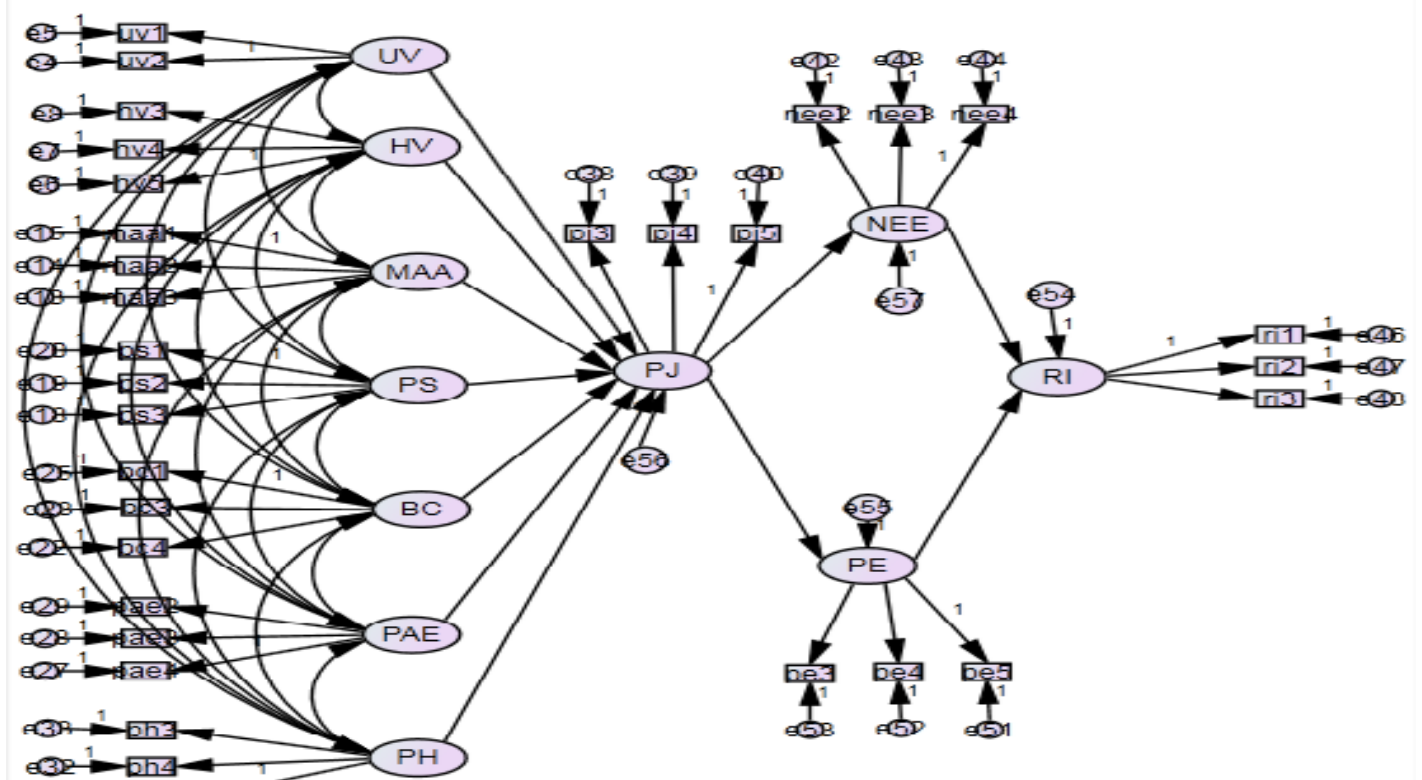

Gambar 1 Struktural Model

Table 2 Hasil Output Regressions Weights

\begin{tabular}{llcc}
\hline \multicolumn{1}{c}{ Keterangan } & \multicolumn{1}{c}{ Relationships } & SPC & P \\
\hline Hipotesis 1 & Utilitarian Value -> Perceived Justice & 0,137 & ${ }^{* * *}$ \\
Hipotesis 2 & Hedonic Value -> Perceived Justice & $-0,002$ & 0,47 \\
Hipotesis 3 & Making an Apology -> Perceived Justice & $-0,153$ & 0,003 \\
Hipotesis 4 & Problem Solving -> Perceived Justice & 0,225 & $* * *$ \\
Hipotesis 5 & Being Courteous -> Perceived Justice & 0,362 & $* * *$ \\
Hipotesis 6 & Providing an Explanation -> Perceived Justice & 0,177 & 0,033 \\
Hipotesis 7 & Prompt Handling -> Perceived Justice & 0,203 & 0,003 \\
Hipotesis 8 & Perceived Justice -> Negative Emotions & $-0,369$ & $* * *$ \\
Hipotesis 9 & Perceived Justice -> Positive Emotions & 0,725 & \multirow{*}{***}{} \\
Hipotesis 10 & Negative Emotions -> Repurchase intention & 0,021 & 0,272 \\
Hipotesis 11 & Positive Emotions -> Repurchase intention & 0,885 & $*$ \\
Variance explained (R2) & & & \\
Perceived Justice & & 0,721 & \\
Negative Emotions & & 0,136 & \\
Positive Emotions & & 0,526 & \\
Repurchase intention & & 0,773 & \\
\hline
\end{tabular}




\section{Making an Apology Terhadap Perceived Justice}

Making an Apology memiliki pengaruh positif terhadap Perceived Justice. Dalam menangani keluhan pelanggan, perusahaan menerima tanggung jawab untuk menyesal atas kegagalan yang terjadi dan meminta maaf kepada pelanggan (Liao 2007). Dalam menangani keluhan pelanggan, perusahaan menerima tanggung jawab atas kegagalan layanan dan menyesal atas apa yang telah terjadi dengan membuat permintaan maaf kepada pelanggan. Fakta bahwa pelanggan telah mengeluh kepada perusahaan menunjukkan bahwa ia telah "menamakan" masalah dan "menyalahkan" perusahaan. Dengan demikian, penolakan tanggung jawab akan diterima dengan buruk (Conlon and Murray 1996). Penelitian menunjukkan permintaan maaf yang berhubungan dengan kepuasaan pelanggan yang lebih tinggi mengikuti kegagalan pelayanan. pengakuan tanggung jawab dapat berupa ekspresi kesalahan. Penelitian dalam keadilan sebelumnya meneliti mengapa membuat permintaan maaf itu penting karena permintaan maaf dipandang sebagai hadiah yang berharga sehingga dapat meningkatkan kembali sebuah hubungan yang baik.

\section{Problem Solving Terhadap Perceived Justice}

Problem Solving memiliki pengaruh positif terhadap Perceived Justice. selain menerima permintaan maaf, pelanggan yang mengeluh tentang masalah pelayanan mengharapkan kesalahan tersebut harus dikoreksi dan diselesaikan untuk mencapai keadilan (Mccoll-Kennedy and Sparks 2003). Kemampuan karyawan untuk memecahkan masalah dalam pelayanan telah terbukti mempengaruhi kepuasan pelanggan dan meningkatkan kualitas dalam pelayanan (Bitner, Booms, and Tetreault 1990). Diluar menerima permintaan maaf, pelanggan yang telah meluangkan waktu dan usaha untuk mengeluh tentang masalah layanan biasanya mengharapkan kesalahan yang harus di perbaiki dan masalah yang yang akan diselesaikan dapat mencapai keadilan (Wirtz and McColl-Kennedy 2010). Indikator yang mempengaruhi perceived justice tersebut adalah Perusahaan asuransi mengkoreksi kesalahan, Perusahaan asuransi cepat menyelesaikan kesalahan yang terjadi, Perusahaan asuransi menanyakan pendapat nasabah tentang menyelesaikan masalah .Sehingga para pelanggan mendapatkan keadilan.

\section{Being Courteous Terhadap Perceived Justice}

Being Courteous memiliki pengaruh positif terhadap Perceived Justice. Perilaku karyawan dalam bekerja harus menunjukkan kesopanan, hormat, keramahan, dan kesabaran saat berinteraksi dengan pelanggan (Liao 2007). Pentingnya sopan santun pada pencapaian kepuasaan pelanggan dan ditemukan bahwa kesopanan karyawan dalam menangani keluhan pelanggan membantu meredakan masalah dalam pikiran pelanggan. Jika karyawan bertindak kasar saat menangani keluhan pelanggan maka hasilnya bisa menjadi bencana. Keadilan dipupuk ketika individu merasa mereka diperlakukan dengan hormat, martabat dan sensitivitas.

\section{Providing an Explanation Terhadap Perceived Justice}

Providing an Explanation memiliki pengaruh positif terhadap Perceived Justice. Menjelaskan kepada pelanggan yang diakibatkan kegagalan dalam pelayanan juga dapat meningkatkan kepuasan pelanggan (Liao 2007). Penjelasan harus menguntungkan dan memberikan efek pada keadilan prosedural dan keadilan distributif (Shaw, Wild, and Colquitt 2003). Menjelaskan kepada pelanggan apa penyebab kegagalan dalam pelayanan yang 
juga dapat meningkatkan kepuasan pelanggan. Dalam konteks lain, penjelasan telah ditemukan untuk membantu penerimaan karyawan dalam menerima berita buruk. Perusahaan asuransi membuat komunikasi terbuka, perusahaan asuransi meningkatkan pengertian kepada pelanggan, dan perusahaan asuransi juga mengambil kesimpulan dari kesalahan yang terjadi sehingga pelanggan mendapatkan perasaan adil.

\section{Prompt Handling Terhadap variabel Perceived Justice}

Prompt Handling memiliki pengaruh positif terhadap variabel Perceived Justice. Penanganan yang cepat mengacu pada respon pelayanan karyawan yang cepat untuk menangani keluhan pelanggan (Liao 2007). keadilan juga menunjukkan bahwa ketepatan waktu dalam pengambilan keputusan dan persepsi mempengaruhi keadilan tentang keputusan yang dicapai. Dalam konteks pemulihan layanan, pelanggan dapat melihat respon pelayanan karyawan yang cepat sebagai hasil yang berharga dan pantas dengan cara yang tepat dalam berkomunikasi dan berinteraksi dengan pelanggan. Tanggapan lambat dapat membuat sinyal kepada pelanggan bahwa perusahaan bersalah dan mengulur-ulur sehingga mengakibatkan ketidakadilan yang dirasakan.

\section{Perceived Justice Terhadap Negative Emotion}

Perceived Justice memiliki pengaruh negatif terhadap Negative Emotion. keadilan biasanya dianggap sebagai konsep kognitif, sedangkan dampaknya telah terbukti dalam hal emosional dan perilaku (Hwang, Kang, and Youn 2016). Emosi dipicu oleh kegagalan dalam pelayanan sehingga mempengaruhi kepuasan pelanggan. Dalam hipotesis yang dilakukan ditemukan sejumlah hubungan yang tidak signifikan dan bertentangan dengan apa yang diprediksikan. Karena dalam penelitian ini kebahagiaan didapat jika mendapatkan keadilan seperti kebanggaan. Namun hasil yang didapat adalah perasaan bersalah dan kemarahan. Sehingga terdapat pengaruh negatif antara kedua variabel. Indikator yang mempengaruhi seperti nasabah mendapatkan informasi yang dibutuhkan, nasabah mendapatkan komunikasi yang baik, nasabah mendapatkan solusi dari masalah yang dihadapi. Namun dalam hal tersebut pelanggan tidak mendapat keadilan yang diinginkan sehingga menyebabkan pengaruh negatif.

\section{Perceived Justice Terhadap Positive Emotion}

Perceived justice berpengaruh positif terhadap positive emotions. Emosi adalah cara konsumen mengatasi keadilan yang tidak dapat dirasakan. Jika apa yang diterima dan dirasakan melebihi apa yang diharapkan, maka mereka akan menganggap sebagai pahala dan menjadi puas. Semakin adil pelanggan mendapatkan apa yang diinginkan maka semakin kecil kemungkinan mereka untuk mengekspresikan perasaan negatif begitu juga sebaliknya. Indikator yang mempengaruhi positif emotions tersebut seperti nasabah mendapatkan informasi yang dibutuhkan, nasabah mendapatkan komunikasi yang baik, nasabah mendapatkan solusi dari masalah yang dihadapi.

\section{Negative Emotion Terhadap Repurchase Intention}

Negative Emotion memiliki pengaruh positif Repurchase Intention. Keadilan masih merupakan konsep baru dalam literatur sosial psikologi. Namun dalam penelitian ini ketika individu tidak mendapatkan hasil yang sesuai mereka akan merasa depresi dan negatif sehingga mereka akan membuat pilihan untuk tidak melakukan repurchase intention. Indikator dalam variabel ini adalah nasabah tidak akan melanjutkan hubungan dengan perusahaan ini, nasabah akan menyebarkan hal negatif dari perusahaan ini, nasabah akan memperingatkan orang lain untuk tidak menggunakan produk ini. 
Dalam penelitian ini jika pelanggan telah mengambil keputusan dalam menggunakan produk, dan senang dengan keputusan yang diambil serta percaya dengan perusahaan tersebut maka tidak mempengaruhi keputusan untuk Repurchase Intention atau tidak bahkan ketika income mereka bertambah mereka akan membeli produk tersebut.

\section{Positive Emotion Terhadap Repurchase Intention}

Terdapat pengaruh positif antara Positive Emotion dengan Repurchase Intention. Ketika pelanggan mendapatkan tawaran pemulihan layanan (service recovery) maka pelanggan akan menggunakan emosi mereka sebagai panduan untuk membuat pilihan agar melakukan Repurchase Intention. Indikator dalam penelitian ini adalah keputusan nasabah dalam menggunakan produk ini adalah keputusan yang bijak, nasabah senang dengan keputusan yang sudah diambil, nasabah juga percaya dengan perusahaan yang dipakai sehingga nasabah akan memperkenalkan produk yang dia pakai kepada keluarga lain serta nasabah minta dikabarkan jika ada manfaat baru dalam produk tersebut

\section{PENUTUP}

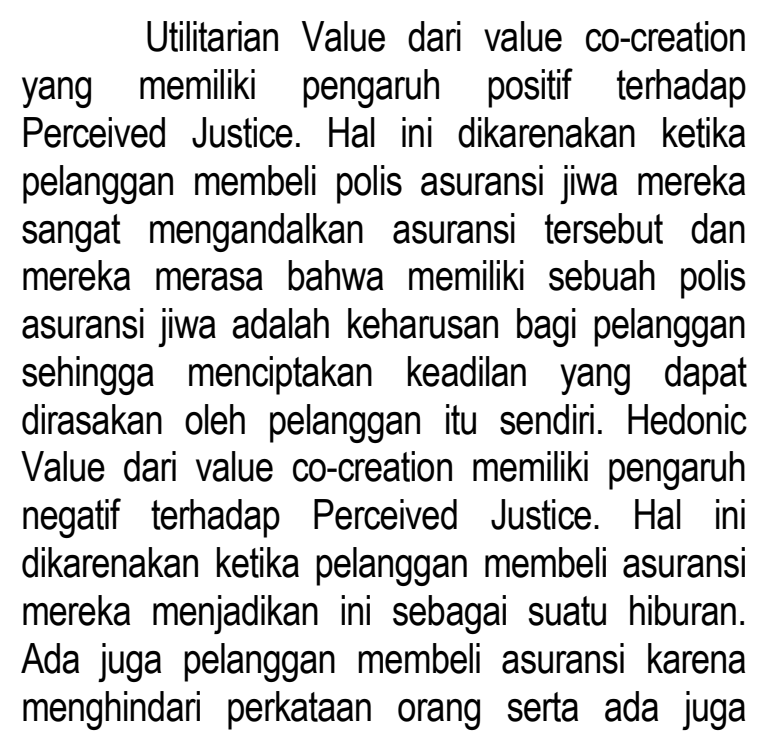

pelanggan yang membeli asuransi karena rasa ingin tahu. Sehingga kebanyakan para pelanggan tidak mengetahui produk apa yang mereka ambil. Ketika terjadi sesuatu terhadap pelanggan maka pelanggan merasa ketidakadilan.

Making an apology dari senvice recovery performance memiliki pengaruh negatif terhadap perceived justice. Hal ini dikarenakan ketika terjadi masalah perusahaan hanya meminta maaf dan bertanggung jawab serta menyesal dengan kesalahan yang diperbuat, namun perusahaan tidak menyelesaikan masalah yang terjadi sehingga banyak pelanggan merasa tidak adil. Problem Solving dari Service Recovery Performance memiliki pengaruh positif terhadap Perceived Justice. Hal ini dikarenakan ketika terjadi masalah perusahaan asuransi mengoreksi kesalahan dan cepet menyelesaikan masalah serta perusahaan menanyakan pendapat nasabah tentang masalah yang dihadapi sehingga pelanggan merasakan keadilan.

Being courteous dari service recovery performance memiliki pengaruh positif terhadap Perceived Justice. Hal ini dikarenakan pelanggan merasakan keadilan ketika terjadi masalah. Karyawan perusahaan asuransi mendengarkan keluhan dengan sopan, dan menghargai keluhan pelanggan serta sabar ketika berinteraksi dengan pelanggan. Providing an Explanation dari Service Recovery Performance memiliki pengaruh positif terhadap Perceived Justice. Hal ini dikarenakan ketika terjadi masalah perusahaan perusahaan membuat komunikasi terbuka untuk menjelaskan hal yang terjadi, dan berusaha meningkatkan pengertian kepada pelanggan serta mengambil kesimpulan dari kesalahan yang terjadi sehingga pelanggan mendapatkan keadilan dari pelayanan pemullihan pelanggan.

Prompt handling dari service recovery performance memiliki pengaruh positif terhadap Perceived Justice. Hal ini dikarenakan perusahaan membuat keputusan dengan tepat dan memberikan hasil yang berharga ketika terjadi masalah. Perusahaan juga memberikan hasil yang layak kepada pelanggan. Dalam hal ini 
pelanggan mendapat keadilan dan tindakan ini juga dapat dilaksanakan oleh perusahaan asuransi manapun agar perusahaan dapat berkembang menjadi semakin baik.

Perceived justice memiliki pengaruh negatif terhadap negative emotions. Dalam hal ini pelanggan tidak mendapatkan informasi yang dibutuhkan serta tidak mendapatkan solusi dari masalah yang terjadi sehingga hal tersebut dapat memberikan emosi yang negatif terhadap pelanggan. perceived justice memiliki pengaruh positif terhadap Positive Emotions. Dalam hal ini pelanggan mendapatkan komunikasi yang baik dari perusahaan ketika terjadi suatu masalah sehingga hal ini berdampak positif terhadap emosi pelanggan.

Negative Emotions tidak memiliki pengaruh terhadap Repurchase Intention. Dalam hal ini ketika pelanggan merasakan emosi yang negatif maka pelanggan tidak akan melanjutkan hubungan dengan perusahaan asuransi tersebut dan akan menyebarkan hal negatif tentang perusahaan serta pelanggan akan memperingatkan orang lain untuk tidak menggunakan produk tersebut. Namun ternyata hal diatas tidak mempengaruhi Repurchase Intention karena selama produk tersebut masih baik dan mereka sudah memutuskan untuk menggunakan produk tersebut maka pelanggan tetap akan melakukan Repurchase Intention. Positive Emotions memiliki pengaruh positif terhadap Repurchase Intention. Hal ini dikarenakan ketika pelaanggan memutuskan untuk membeli produk ini pelanggan merasa ini adalah keputusan yang bijak sehingga pelanggan senang dengan keputusan yang diambil. Pelanggan juga melihat bahwa perusahaan tersebut dapat dipercaya sehingga Repurchase Intention dapat dilakukan bahkan pelanggan akan memperkenalkan produk ini kepada keluarga lain.

Penelitian selanjutnya dapat menggunakan dimensi dari varibel lain untuk menguji penyebab service failure dan indikator yang berbeda dari penelitian ini. Metode penelitian yang digunakan dalam penelitian ini bersifat kuantitatif. Untuk penelitian selanjutnya disarankan untuk menambahkan menggunakan metode kualitatif melalui wawancara atau focus group discussion atau gabungan antara metode kuantitatif dan kualitatif untuk mendapatkan pemahaman yang lebih mendalam dari responden. Beberapa variabel memiliki hasil dengan pengaruh negatif, sehingga peneliti selanjutnya dapat menggunakan indikator lain sehingga menghasilkan pengaruh yang positif

\section{REFERENCES:}

Andries, A Maria. 2011. "Positive and Negative Emotions within the Organizational Context." Global Journal of Human Social Science 11 (9): 26-39.

Barakat, Livia L., Jase R. Ramsey, Melanie P. Lorenz, and Marlusa Gosling. 2015. "Severe Service Failure Recovery Revisited: Evidence of Its Determinants in an Emerging Market Context." International Journal of Research in Marketing 32 (1): 113-16. https://doi.org/10.1016/j.jiresmar.2014.10.001.

Bitner, Mary Jo, Bernard H. Booms, and Mary Stanfield Tetreault. 1990. "The Service Encounter: Diagnosing Favorable and Unfavorable Incidents." Journal of Marketing 54 (1): 71. https://doi.org/10.2307/1252174.

Bolton, Lisa E., and Anna S. Mattila. 2015. "How Does Corporate Social Responsibility Affect Consumer Response to Service Failure in Buyer-Seller Relationships?" Journal of Retailing 91 (1): 140-53. https://doi.org/10.1016/j.jretai.2014.10.001.

Chebat, Jean Charles, and Witold Slusarczyk. 2005. "How Emotions Mediate the Effects of Perceived Justice on Loyalty in Service Recovery Situations: An Empirical Study." Journal of Business Research 58 (5): 664-73. https://doi.org/10.1016/j.jbusres.2003.09.005.

Chen, Chih Cheng Volvic, and Chih Jou Chen. 2017. "The Role of Customer Participation for Enhancing Repurchase Intention." Management Decision 55 (3): 547-62. https://doi.org/10.1108/MD-06-2016-0380. 
Conlon, Donald E., and Noel M. Murray. 1996. "Customer Perceptions of Corporate Responses to Product Complaints: The Role of Explanations." Academy of Management Journal 39 (4): 1040-56. https://doi.org/10.2307/256723.

Darwin, Steven, Yohanes Sondang, and Et Al. 2014. "ANALISIS PENGARUH KUALITAS LAYANAN TERHADAP LOYALITAS PELANGGAN DENGAN KEPUASAN DAN KEPERCAYAAN PELANGGAN SEBAGAI VARIABEL INTERVENING PADA ASURANSI JIWA MANULIFE INDONESIA - SURABAYA Steven." Jurnal Manajemen Pemasaran Petra 2 (1): 1-12.

Ebrahim, Reham, Ahmad Ghoneim, Zahir Irani, and Ying Fan. 2016. "A Brand Preference and Repurchase Intention Model: The Role of Consumer Experience." Journal of Marketing Management 32 (13-14): 123059. https://doi.org/10.1080/0267257X.2016.1150322.

Grönroos, Christian. 2011. "Value Co-Creation in Service Logic: A Critical Analysis." Marketing Theory 11 (3): 279-301. https://doi.org/10.1177/1470593111408177.

Hoffman, K. Douglas, and Scott W. Kelley. 2000. "Perceived Justice Needs and Recovery Evaluation: A Contingency Approach." European Journal of Marketing 34 (3/4): 418-33. https://doi.org/10.1108/03090560010311939.

Holbrook, Morris B. 2006. "Consumption Experience, Customer Value, and Subjective Personal Introspection: An Illustrative Photographic Essay." Journal of Business Research 59 (6): 714-25. https://doi.org/10.1016/j.jbusres.2006.01.008.

Hwang, Hee Joong, Min Jeong Kang, and Myoung Kil Youn. 2016. "Experiential Regret in Service Failure: The Role of Service Justices." Journal of Transnational Management. https://doi.org/10.1080/15475778.2016.1120609.

Imperatori, Barbara, and Dino Ruta. 2014. "Social Media in Human Resources Management Article Information :" Social Media in Human Resources Management, 181-200.

Kartajaya, H. 2009. "New Wave Marketing." Jakarta: Gramedia Pustaka Utama.

La, Suna, and Beomjoon Choi. 2019. "Perceived Justice and CSR after Service Recovery." Journal of Services Marketing 33 (2): 206-19. https://doi.org/10.1108/JSM-10-2017-0342.

Liao, Hui. 2007. "Do It Right This Time: The Role of Employee Service Recovery Performance in CustomerPerceived Justice and Customer Loyalty after Service Failures." Journal of Applied Psychology 92 (2): 47589. https://doi.org/10.1037/0021-9010.92.2.475.

Luo, Anqi, Priyanko Guchait, Lindsey Lee, and Juan M. Madera. 2019. "Transformational Leadership and Service Recovery Performance: The Mediating Effect of Emotional Labor and the Influence of Culture." International Journal of Hospitality Management 77 (May): 31-39. https://doi.org/10.1016/j.jhm.2018.06.011.

Maneesh Kumar Niraj Kumar. 2016. "Three Dimensions of Service Recovery: Examining Relationship and Impact."

Mccoll-Kennedy, Janet R., and Beverley A. Sparks. 2003. "Application of Fairness Theory to Service Failures and Service Recovery." Journal of Service Research 5 (3): 251-66. https://doi.org/10.1177/1094670502238918.

Park, Joohyung, and Sejin Ha. 2016. "Co-Creation of Service Recovery: Utilitarian and Hedonic Value and PostRecovery Responses." Journal of Retailing and Consumer Services 28: 310-16. https://doi.org/10.1016/j.jretconser.2015.01.003.

Ramaswamy, Venkat. 2008. "Co-Creating Value through Customers' Experiences: The Nike Case." Strategy and Leadership 36 (5): 9-14. https://doi.org/10.1108/10878570810902068.

Roggeveen, Anne L., Michael Tsiros, and Dhruv Grewal. 2012. "Understanding the Co-Creation Effect: When Does Collaborating with Customers Provide a Lift to Service Recovery?" Journal of the Academy of Marketing Science 40 (6): 771-90. https://doi.org/10.1007/s11747-011-0274-1.

Schoefer, Klaus, and Christine Ennew. 2005. "The Impact of Perceived Justice on Consumers' Emotional Responses to Service Complaint Experiences." Journal of Services Marketing 19 (5): 261-70. https://doi.org/10.1108/08876040510609880.

Shaw, John C., Eric Wild, and Jason A. Colquitt. 2003. "To Justify or Excuse?: A Meta-Analytic Review of the Effects of Explanations." Journal of Applied Psychology. https://doi.org/10.1037/0021-9010.88.3.444. 
Simanjuntak, Megawati, Hanum Rachmawati Nur, Bagus Sartono, and Mohamad Fazli Sabri. 2020. "A General Structural Equation Model of the Emotions and Repurchase Intention in Modern Retail." Management Science Letters 10 (4): 801-14. https://doi.org/10.5267/j.msl.2019.10.017.

Wardhana, Aditya. 2015. "Analisis Faktor-Faktor Pembentuk Service Recovery Pada Top Brand Perusahaan Penyedia Jasa Rental Mobil Di Indonesia Berdasarkan Persepsi Pelanggan Korporasi." SNaPP, no. 2013: 15-22.

Wirtz, Jochen, and Janet R. McColl-Kennedy. 2010. "Opportunistic Customer Claiming during Service Recovery." Journal of the Academy of Marketing Science 38 (5): 654-75. https://doi.org/10.1007/s11747-009-0177-6.

WM Shaleha, Al Asy Ari Adnan Hakim, and Nisrina Hamid. 2020. "Pengaruh Hedonic Shopping Value, Utilitarian Value, Dan Store Atmosphere Terhadap Impulse Buying Pada Minnisou Lippo Plaza Kendari." JBMP Jurnal Bisnis Manajemen Dan Perbankan 6: 91-99. https://doi.org/https://doi.org/10.21070/jbmp.v6i2.678. 
